\title{
Curative and Protective Effect of Salvia Officinalis Oil on Isoprenaline- Induced Congestive Heart Failure in Rats
}

\author{
Sarah Mohamed Yousry ${ }^{1}$, Ragia Ali Mahmoud Taha ${ }^{1}$, Hossny Awad El-Banna ${ }^{2}$, Shimaa R. \\ EMAM $^{2 *}$
}

${ }^{1}$ Department of Pharmacology and Toxicology, Faculty of Pharmacy (Girls) AL-Azhar University, Cairo, Egypt; ${ }^{2}$ Department of Pharmacology, Faculty of Veterinary Medicine, Cairo University, Cairo 12613, Egypt.

\begin{abstract}
Congestive heart failure (CHF) is a chronic progressive condition associated with high mortality. The curative and prophylactic role of sage oil on Isoprenaline (ISO) induced CHF were evaluated in rats and compared with the reference digoxin. Sage oil was used at two doses of $50 \mathrm{and} 100 \mathrm{mg} / \mathrm{kg}$. Blood samples werescreened for cardiac markers $(\mathrm{CK}-\mathrm{MB}$ and $\mathrm{cTnI})$ and inflammatory marker $(\mathrm{TNF}-\alpha)$. Heart tissues were used for heart index calculation, measurement of oxidative stress markers (MDA and NO, TAC), histopathological examination for Hematoxylin and Eosin, Masson stain for collagen fiber content and immunohistochemical stain for caspase 3 as a marker of apoptosis. Administration of sage oil as a prophylactic measure significantly improves ISOinducedalterations in most of parameters measured in a dose dependent manner. Pretreatment of ISO treated rats with sage oil $50 \mathrm{and} 100 \mathrm{mg} / \mathrm{kg}$ showed partial amelioration of $\mathrm{CHF}$ in a dose dependent manner with significant lower effectthandigoxin. Further investigation for sage oil curative effect on $\mathrm{CHF}$ is recommended.
\end{abstract}

Keywords | Isoprenaline, Saga oil, Congestive heart failure, Curative, Protective

Received | June 17, 2021; Accepted | August 07, 2021; Published | September 25, 2021

*Correspondence | Shimaa R. Emam, Department of Pharmacology, Faculty of Veterinary Medicine, Cairo University, Cairo 12613, Egypt; Email: shaimaaramadan644@gmail.com

Citation | Yousry SM, Taha RAM, El-Banna HA, Emam SR (2021). Curative and protective effect of salvia officinalis oil on isoprenaline-induced congestive heart failure in rats. Adv. Anim. Vet. Sci. 9(11): 1895-1907.

DOI | http://dx.doi.org/10.17582/journal.aavs/2021/9.11.1895.1907

ISSN (Online) | 2307-8316; ISSN (Print) | 2309-3331

Copyright $\odot 2021$ Yousry et al. This is an open access article distributed under the Creative Commons Attribution License, which permits unrestricted use, distribution, and reproduction in any medium, provided the original work is properly cited.

\section{INTRODUCTION}

$\mathrm{T}_{\mathrm{i} \text { son }}$ he overall prevalence of congestive heart failure $(\mathrm{CHF})$ is still increasing with a high mortality, because of the ageing of the population and the success in prolonging survival in patients suffering cardiac disease (McMurray et al., 2012). Isoprenaline (ISO) is a nonselective $\beta_{1}-$ and $\beta_{2}$ - adrenergic receptor agonist and large doses can induce heart failure by several mechanisms, including an increase in intracellular cyclic adenosine monophosphate (cAMP), calcium overload, ischemia, and oxidative stress (Remião et al., 2001; Ellison et al., 2007). ISO-induced CHF model is well established noninvasive model characterized by an extraordinary technical simplicity and excellent reproducibility (Grimm et al., 1998), witha very similar homodynamic and pathological changes to human chronic heart failure (Garjani et al., 2011). Moreover, isoproterenol $(5 \mathrm{mg} / \mathrm{kg} / \mathrm{d}, 7$ days) is a well-known cardiotoxic agent according to numerous published researches (Anderson et al., 2008; Drews et al., 2010; Zhou et al., 2017). In addition, isoproterenol also, cause severe myofibrillar degeneration of the myocardial tissue (Patel et al., 2010).

Salvia officinalis L. have been used as traditional herbal medicine and its essential oils have been used in the treatment of large range of diseases like, nervous system, heart and blood circulation, respiratory, digestive, metabolic and endocrine diseases (Bouajaj et al., 2013; Hamidpour et al., 2014). As essential oils are very important sources for the screening of anticancer, antimicrobial, antioxidant, and free radical scavenging agents (Hussain et al., 2011). Salvia officinalis (Common sage) is considered to have 
the highest amount of essential oil compared to the other species of Salvia (Rami and Li, 2011). The co-treatment of ethanolic extracts of Salvia officinalis for 4 weeks markedly prevented chlorpyrifos and methomyl-induced biochemical and histopathological alterations in heart and testes of rats through potentiation of the antioxidant defense system. This was proved at the cardiac level through biochemical analysis of CK-MB, Glutathione content, lipid peroxidation (MDA), glutathione peroxidase (GPx), glutathione-S-transferase (GST) and SOD (superoxide dismutase) activities (Ahmed et al., 2017). Salvia officinalis oil pre-co-post-treatment ameliorated altered biochemical cardiac, oxidative stress, antioxidant, pro-inflammatory parameters and altered serum lipid profile caused by 5Fluorouracil induced cardiotoxicity in rats (Safwat and Mohammed, 2015).

Therefore, the present study aimed to evaluate the prophylactic and the curative role of sage oil on ISOinduced CHF in rats and compare its effect with the reference digoxin, which is used for treatment of HF. Furthermore, the effect of sage oil and digoxin combination for treatment of $\mathrm{CHF}$ was evaluated with investigation for the possible underlying mechanisms.

\section{MATERIALS AND METHODS}

\section{DRUGS AND CHEMICALS}

Sage oil was obtained by cold extraction from AOS Products Private Limited Co., as pure oil (South Side GT Road, Ghaziabad, India); it was suspended in water using $0.1 \mathrm{ml}$ tween 80 . Digoxin was commercially available as Lanoxine $0.25 \mathrm{mg}$ tablets, Glaxo Smith Kline, Cairo, Egypt it was finely grinded and suspended in distilled water for oral administration. Isoprenaline used in this experiment was imported from Nanjing Bolka International Co. Ltd. China. It was white to off-white powder with a potency of $(99.8 \%)$, prepared by dissolving in normal saline for subcutaneous injection chemicals used in the present study was of analytical grade; Tween 80 (Merck, Germany), Diethyl ether (Merck, Germany).

\section{KITS}

Creatine Kinase-MB: (Bio-Med diagnostic, Egypt), Troponin I (cTnI) Elisa kit (Competitive ELISA): (My BioSource, USA), Malondialdehyde (MDA): (Life Span BioScience, Inc. United states), Nitric oxide (NO) assay: (Stressgen, United states), Total antioxidant capacity (TAC) (My BioSource, USA), Tumor necrotic factor alpha (TNF- $\alpha$ ) enzyme -linked immunosorbent assay (EIISA) kit: (CUSABIO, China)

\section{Animals}

Adult male albino rats weighting (150-180g) were obtained from the animal house of National Research Center, Cairo, Egypt. They were housed under appropriate controlled conditions ( $12 \mathrm{~h}$ light $/ 12 \mathrm{~h}$ dark), $25 \pm 2^{\circ} \mathrm{C}$ environmental temperature with free access to water and standard pellet rat diet. Albino rats were acclimatized to adapt themselves with the new location at the animal house of Faculty of Veterinary, Cairo University, for 2 weeks in separate cages prior to start of the experiment. All Animal's procedures were performed in accordance with the Guidelines for animal experiments set by the Ethical Committee of the Veterinary Medicine Cairo University.

\section{EXPERIMENTAL DESIGN}

Fifty adult male albino rats were divided equally into ten groups, as the follows: Group I (Control group): Rats were received $0.1 \mathrm{ml}$ tween 80 in distilled water orally by gastric gavage and injected subcutaneously with saline. Group II (sage oil $50 \mathrm{mg}$ ): Rats were received daily sage oil by oral gavage $50 \mathrm{mg} / \mathrm{kg}$ for 3 weeks (El-Banna et al., 2013). Group III (sage oil 100mg): Rats were received daily sage oil by oral gavage $100 \mathrm{mg} / \mathrm{kg}$ for 3 weeks. Group IV (ISO group): Rats were received subcutaneous (s.c) injection of isoprenaline dissolved in normal saline $(85 \mathrm{mg} / \mathrm{kg} /$ day for 2 consecutive days and kept for 15 days for induction of $\mathrm{CHF}$ following 1st ISO injection (Parveen et al., 2011). Group $\mathrm{V}$ (sage oil $50 \mathrm{mg}+\mathrm{ISO}$ ): Rats were received daily sage oil by oral gavage $50 \mathrm{mg} / \mathrm{kg}$ for 7 days then ISO $85 \mathrm{mg} / \mathrm{kg}$ was injected at day 8 th and $9^{\text {th }}$ and sage oil was concurrently administered and continued for another 15 days following $1^{\text {st }}$ isoprenaline injection (prophylactic sage oil 50). Group VI (sage oil $100 \mathrm{mg}+\mathrm{ISO}$ ): Rats were received daily sage oil by oral gavage $100 \mathrm{mg} / \mathrm{kg}$ for 7 days then ISO $85 \mathrm{mg} /$ $\mathrm{kg}$ was injected for 2 days and sage oil was concurrently administered and continued for another 15 days following $1^{\text {st }}$ isoprenaline injection (prophylactic sage oil 100). Group VII (digoxin $1 \mathrm{mg}+\mathrm{ISO}$ ): Rats were received daily digoxin by oral gavage $1 \mathrm{mg} / \mathrm{kg}$ for 7 days (Wang et al., 2020) then ISO $85 \mathrm{mg} / \mathrm{kg}$ was injected for 2 days and digoxin was concurrently administered and continued for another 15 days following $1^{\text {st }}$ isoprenaline injection (prophylactic digoxin 1mg).

Group VIII (ISO + sage oil 50mg): Rats were ISO for 2 consecutive days and kept for 15 days then received daily sage oil dose of $50 \mathrm{mg} / \mathrm{kg}$ orally for 15 days (curative sage oil mg). Group IX (ISO + digoxin 1mg): Rats were received ISO (s.c) for 2 consecutive days and kept for 15 days, then received daily digoxin $1 \mathrm{mg} / \mathrm{kg}$ orally for 15 days (curative digoxin 1mg). Group X (ISO + (sage oil 50mg and digoxin $0.5 \mathrm{mg}$ ): Rats received ISO (s.c) for 2 consecutive days and kept for 15 days then received both (sage oil $50 \mathrm{mg} / \mathrm{kg}$ and digoxin $0.5 \mathrm{mg} / \mathrm{kg}$ ) orally for 15 days (curative sage oil $50 \mathrm{mg} /$ digoxin $0.5 \mathrm{mg}$ ). 
Twenty four hours after the last dose of each group, rats were weighted and blood samples were obtained from the retro-orbital junction and allowed to clot. Then tubes were centrifuged at 5000 revolutions per minute (rpm) for 10 minutes for serum separation and the samples were stored at $-80^{\circ} \mathrm{C}$ till analysis. Rats were anesthetized by diethyl ether for electrocardiographic recording and sacrificed. All heart tissues were dissected, weighted, washed with ice cold saline for tissue homogenate biochemical analysis or kept in $10 \%$ formalin for histological and immunohistochemical examination.

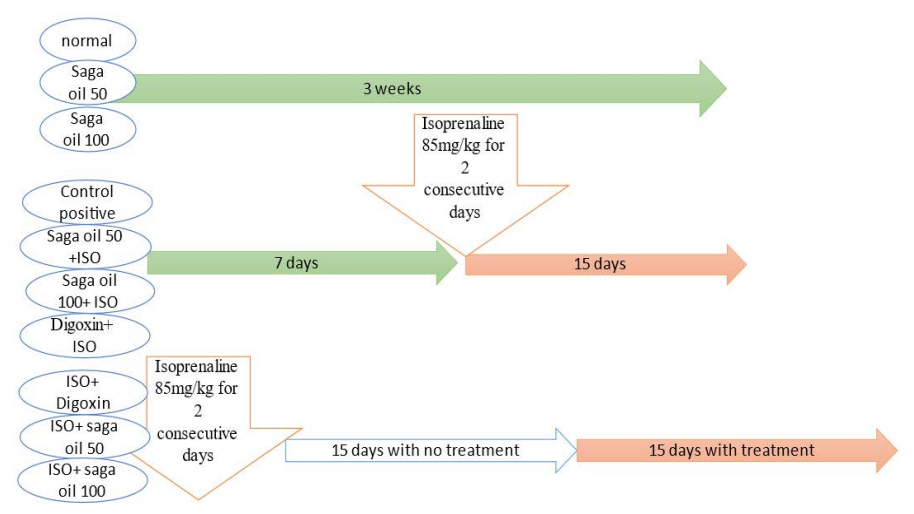

\section{Methods}

\section{Electrocardiography (ECG)}

Rats were anesthetized by dimethyl ether and ECG was recorded for 1 minute using ECG Power lab module which consists of Power lab/ 8spandAnimalBio- Amplifier, Australia, in addition to Lab Chart 7 software with ECG analyzer (Jensen et al., 1984; Hajrasouliha et al., 2004).

\section{CARDIOTOXICITY MARKERS}

After the hemodynamic measurements, the animals were anesthetized and the hearts were removed and weighted. Then the heart tissues to body weight ratios were calculated according to the formula (heart weight/body weight $\times 100$ ). Determination of serum creatine kinase $\mathrm{MB}$ enzyme activity: Guided by (Gerhardt and Waldenstrom., 1979). Determination of serum level of cardiac troponin I (cTnI): using Elisa kit (Competitive ELISA). The cTnI ELISA kit applies the competitive enzyme immunoassay technique utilizing a polyclonal anti-cTnI antibody and a cTnI-HRP conjugate.

\section{OXIDATIVE STRESS AND ANTIOXIDANT MARKERS}

Determination of cardiac content of malondialdehyde (MDA); In contrast to typical Sandwich ELISA assays, in competition assay the greater the amount of antigen the sample, the lower the color development and optical density reading (Ohkawa et al., 1979). Determination of cardiac nitric oxide [nitrate /nitrite ( $\mathrm{NO}-/ \mathrm{NO}-$ )] nitric oxide assay kit is a complete kit for the quantitative determination of nitrite and nitrate in biological fluids. (Stuehr and Marletta, 1985). Determination of cardiac content of total antioxidant capacity (TAC) ELISA kit (Koracivic et al., 2001).

\section{INFLAMMATORY MARKER}

Determination of serum tumor necrotic factor alpha (TNF - $\alpha$ ) using conducted by ElISA kit (Markham et al., 1995).

\section{Histological EXAMination}

Heart tissues sections of each group mounted on slides and subjected to Hematoxylin and eosin ( $\mathrm{H}$ and $\mathrm{E}$ ) stain following the method described by (Kiernan, 2001). Paraffin tissue blocks were prepared for sectioning at 4 microns thickness by slide microtome. The obtained tissue sections were collected on glass slide and deparaffinized. After that, sections were stained with Hematoxylin and Eosin for routine histological examination. Masson's trichrome stain for demonstration of collagen fibers was performed following (Suvarna et al., 2012). Immunohistochemical staining for caspase 3 was guided by (Bancroft and Gamble, 2008) using a rabbit polyclonal antibody (Lab Vision Corporation Laboratories, catalogue number PA1-26426). Non-specific background was eliminated by adding serum blocking solution. Area percent of collagen fibers in Masson's trichrome stained section, and Area \% of caspase 3 immunoreactive cells and area percent (percentage proportion) of caspase 3 immuno positive cells were measured under the light microscope. Data were obtained using Leicamicro systems LTD (DFC295) software image analysis computer system (Germany) in Dentistry Research and Equipment unit, Faculty of Dentistry, Cairo University. The image was analyzed by image $\mathrm{J}$ software program (http://rsbweb.nih.govlijldownload.html).

\section{Statistical Analysis}

The morphometric and the biochemical measurements were statistically analyzed using one-way analysis of variance (ANOVA) followed by Tukey's test for multiple comparisons. Data was expressed as mean \pm standard error of mean (SEM). The value of probability $(\mathrm{P})<0.05$ was considered significant. Graph pad Prism computer program (2007) was used Armitage and Berry (1987).

\section{RESULTS AND DISCUSSION}

\section{EFFECT OF ISOPRENALINE ON ECG PARAMETERS}

Administration of ISO significantly increased heart rate and $\mathrm{R}$ amplitude compared to control group. Prophylactic administration of sage oil or digoxin significantly increased $\mathrm{R}$ amplitude. However, neither sage oil $100 \mathrm{mg}$ nor digoxin affected QRS interval or ST depression induced by ISO. Additionally sage oil $50 \mathrm{mg}$ didn't improve any of ISO induced ECG changes as illustrated in Figures 1, 2. 
OPEN ठ ACCESS

However, treatment with digoxin $1 \mathrm{mg} / \mathrm{kg} / \mathrm{day} / \mathrm{p} .0$ either alone or in combination with sage oil at dose of $0.5 \mathrm{mg}$ and $50 \mathrm{mg} / \mathrm{kg} /$ day $/$ p.o, significantly reduced heart rate, reduced the depression in ST height and increased R amplitude Sage oil administration didn't affect heart rate, QRS or St depression as compared to CHF. Furthermore neither digoxin $1 \mathrm{mg}$ nor combined (sage oil $50 \mathrm{mg}$ and digoxin $1 \mathrm{mg}$ ) affected QRS interval as shown in Figures 3, 4.

\begin{tabular}{|c|c|}
\hline Control & \\
\hline Sage oil 50mg & \\
\hline Sage oil 100mg & \\
\hline ISO (CHF) & - \\
\hline $\begin{array}{l}\text { Prophylactic sage oi } \\
50 \mathrm{mg}+\text { ISO }\end{array}$ & \\
\hline $\begin{array}{l}\text { Prophylactic } \\
\text { sageoil100mg+ ISO }\end{array}$ & \\
\hline $\begin{array}{l}\text { Prophylactic } \\
\text { digoxinlmg+ ISO }\end{array}$ & \\
\hline
\end{tabular}

Figure 1: Effect of sage oil on ECG records in isoprenalineinduced CHF in rats (prophylactic).

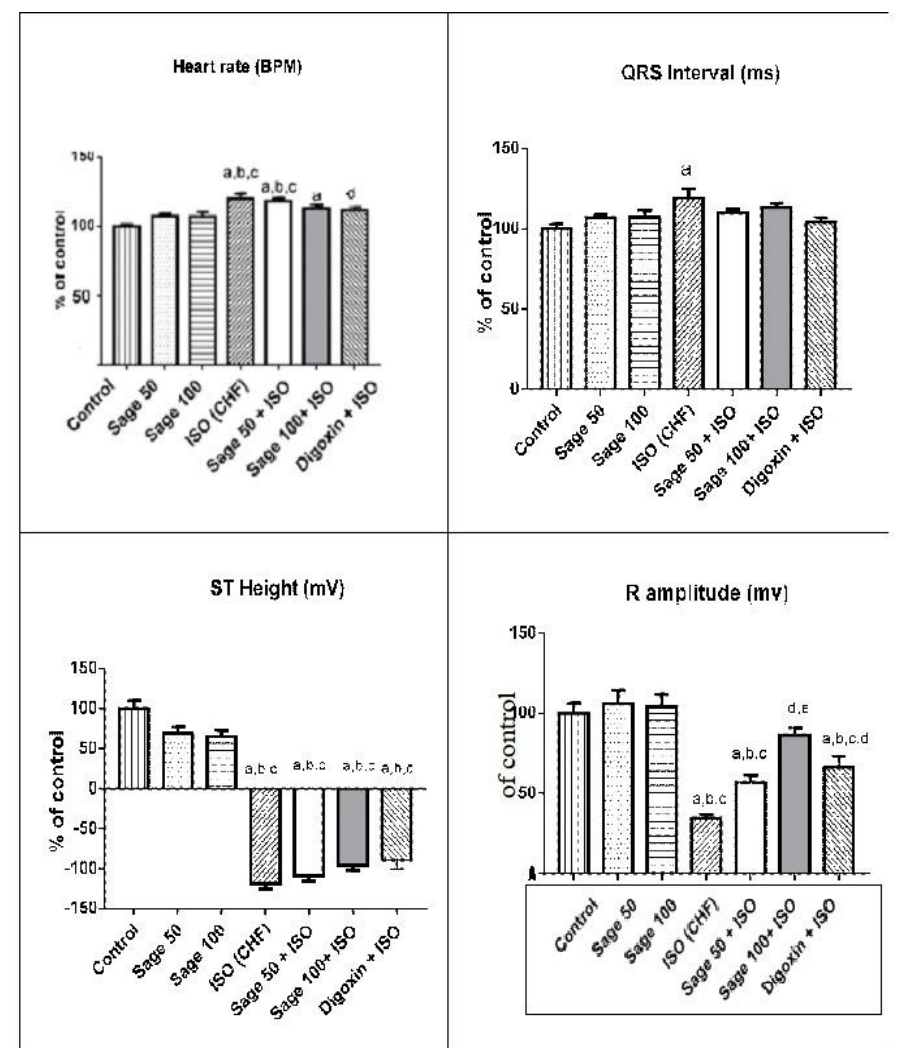

Figure 2: Effect of sage oil on ECG parameters in isoprenaline- induced $\mathrm{CHF}$ in rats. Data was expressed as mean $\pm \mathrm{SE}, \mathrm{n}=5, \mathrm{a}, \mathrm{b}, \mathrm{c}, \mathrm{d}$ or e significantly different from the control, sage oil $50 \mathrm{mg}$, sage oil $100 \mathrm{mg}$, ISO group or sage oil $50+$ ISO at $(\mathrm{P}<0.05)$.
Advances in Animal and Veterinary Sciences

\begin{tabular}{|c|c|}
\hline Control & \\
\hline Sage oil $50 \mathrm{mg}$ & \\
\hline Iso & 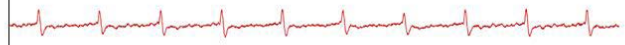 \\
\hline ISO+ sage oil 50mg & \\
\hline ISO+digoxin $1 \mathrm{mg}$ & hater \\
\hline $\begin{array}{l}150+\text { combined (sage } \\
\text { somg digoxin } 0.5 \mathrm{mg})\end{array}$ & her \\
\hline
\end{tabular}

Figure 3: Effect of sage oil on ECG records in isoprenalineinduced $\mathrm{CHF}$ in rats (curative)
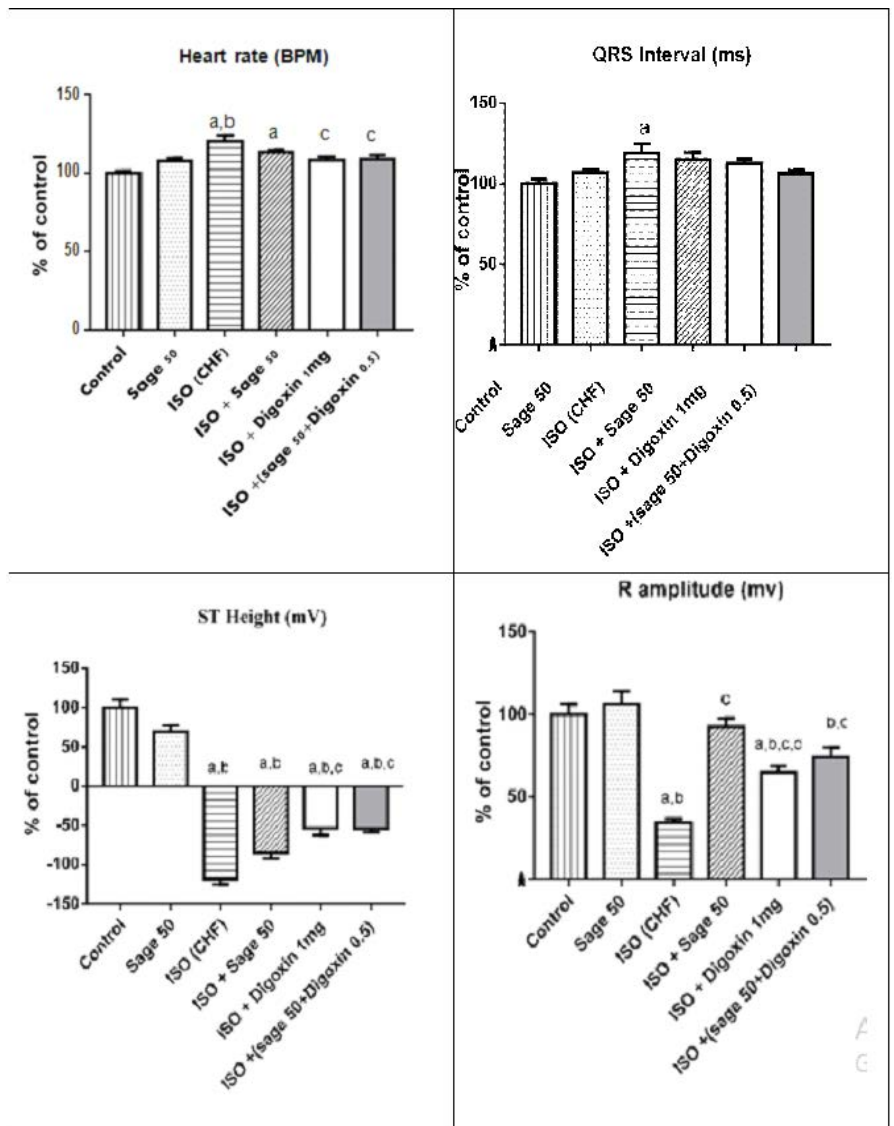

Figure 4: Effect of sage oil on ECG parameters in isoprenaline-induced $\mathrm{CHF}$ in rats (curative). Data was expressed as mean $\pm \mathrm{SE}, \mathrm{n}=5$. a,b,c,d or e significantly different from the control, sage oil $50 \mathrm{mg}$, ISO group, ISO+sage oil 50, ISO+Digotoxin $1 \mathrm{mg}$, ISO+ (sage oil $50+$ Digotoxin 0.5$)$ at $(\mathrm{P}<0.0)$.

\section{CARDIOTOXICITY MARKERS HEART INDEX AND CARDIAC MARKERS}

Administration of isoprenaline significantly increased heart index, serum activity of creatine kinase isoenzyme-MB (CK-MB) and cardiac troponin I level (cTnI) compared to the control group. Prophylactic administration of saga oil significantly decreased the heart index, $\mathrm{CK}-\mathrm{MB}$ and serum level ofc TnI compared to CHF group but didn't normalizeit. 
Table 1: Effect of sage oil on heart index, serum creatinekinase-MB isoenzyme (CK- MB) activity and cardiac troponinI (cTnI) serum level inisoprenaline-induced $\mathrm{CHF}$ in rats (prophylactic).

$\begin{array}{llll}\text { Group/Parameters } & \text { Heart index }(\mathbf{m g} / \mathbf{g m}) & \text { CK-MB }(\mathbf{u} / \mathbf{L}) & \text { Troponin I (ng/ml) } \\ \text { Control } & 0.308 \pm 0.007 & 123.1 \pm 1.028 & 0.13 \pm 0.012 \\ \text { Sage oil 50mg } & 0.32 \pm 0.009 & 121.9 \pm 3.432 & 0.147 \pm 0.016 \\ \text { Sage oil 100mg } & 0.311 \pm 0.012 & 119.8 \pm 2.59 & 0.128 \pm 0.017 \\ \text { ISO (CHF) } & 0.448 \pm 0.007^{\text {ab, }, \mathrm{c}} & 362.7 \pm 1.694^{\mathrm{a}, \mathrm{b}, \mathrm{c}} & 2.4 \pm 0.059^{\mathrm{a}, \mathrm{b}, \mathrm{c}} \\ \text { Prophylactic sage oil 50mg+ ISO } & 0.409 \pm 0.005^{\mathrm{a}, \mathrm{b}, \mathrm{c}} & 310.2 \pm 2.456^{\mathrm{a}, \mathrm{b}, \mathrm{c}, \mathrm{d}} & 2.047 \pm 0.075^{\mathrm{a}, \mathrm{b}, \mathrm{c}, \mathrm{d}} \\ \text { Prophylactic sage oil 100mg + ISO } & 0.391 \pm 0.009^{\mathrm{a}, \mathrm{b}, \mathrm{c}, \mathrm{d}} & 237.5 \pm 2.66^{\mathrm{a}, \mathrm{b}, \mathrm{d}, \mathrm{d}, \mathrm{e}} & 1.693 \pm 0.071^{\mathrm{a}, \mathrm{b}, \mathrm{c}, \mathrm{d}, \mathrm{e}} \\ \text { Prophylactic digoxin 1mg + ISO } & 0.368 \pm 0.007^{\mathrm{a}, \mathrm{b}, \mathrm{d}, \mathrm{d}, \mathrm{e}} & 173.4 \pm 6.588^{\mathrm{a}, \mathrm{b}, \mathrm{c}, \mathrm{d}, \mathrm{e}, \mathrm{f}} & 0 \pm 0.058^{\mathrm{a}, \mathrm{b}, \mathrm{b}, \mathrm{d}, \mathrm{e}, \mathrm{f}}\end{array}$

N.B: Mortality rate; control (0/10), sage oil 50 (0/10), sage oil 100 (0/10), ISO (3/10), prophylactic sage oil 50+ISO (2/10), prophylactic sage oil 100+ ISO (2/10), prophylactic digoxin $1 \mathrm{mg}+\mathrm{ISO}(1 / 10)$. Data was expressed as mean $\pm \mathrm{SE}, \mathrm{n}=5$. a, b, c, d, e, or f: Significantly different from the control, sage oil $50 \mathrm{mg}$, sage oil $100 \mathrm{mg}$, ISO (CHF), prophylactic sage oil $50 \mathrm{mg}+$ ISO or prophylactic sage oil $100 \mathrm{mg}+$ ISO respectively at $(\mathrm{P}<0.05)$.

Table 2: Effect of sage oil on heart index, serum creatine kinase-MB isoenzyme (CK- MB) activity and cardiac troponin $\mathrm{I}(\mathrm{c} T \mathrm{nI})$ serum level in isoprenaline-induced $\mathrm{CHF}$ in rats (curative).

$\begin{array}{llll}\text { Group/ Parameters } & \text { Heart index }(\mathbf{m g} / \mathbf{g m}) & \text { CK-MB } \mathbf{( u /} / \mathbf{L}) & \text { Troponin I (ng/ml) } \\ \text { Control } & 0.308 \pm 0.007 & 123.1 \pm 1.028 & 0.13 \pm 0.012 \\ \text { Sage oil 50mg } & 0.32 \pm 0.009 & 121.9 \pm 3.432 & 0.147 \pm 0.016 \\ \text { ISO (CHF) } & 0.448 \pm 0.007^{\mathrm{a}, \mathrm{b}} & 362.7 \pm 1.694^{\mathrm{a}, \mathrm{b}} & 2.4 \pm 0.059^{\mathrm{a}, \mathrm{b}} \\ \text { ISO+ sage oil 50mg } & 0.381 \pm 0.009^{\mathrm{a}, \mathrm{b}, \mathrm{c}} & 164.8 \pm 2.391^{\mathrm{a}, \mathrm{b}, \mathrm{c}} & 1.08 \pm 0.076^{\mathrm{a}, \mathrm{b}, \mathrm{c}} \\ \text { ISO+ digoxin } 1 \mathrm{mg} & 0.346 \pm 0.007^{\mathrm{c}} & 157.6 \pm 3.249^{\mathrm{a}, \mathrm{b}, \mathrm{c}} & 0.862 \pm 0.037^{\mathrm{a}, \mathrm{b}, \mathrm{c}} \\ \text { ISO+ combined (sage oil } & 0.356 \pm 0.011^{\mathrm{a}, \mathrm{c}} & 132.7 \pm 2.099^{\mathrm{c}, \mathrm{d}, \mathrm{e}} & 0.352 \pm 0.025^{\mathrm{c}, \mathrm{d}, \mathrm{e}} \\ \text { 50mg+digoxin 0.5mg) } & & & \end{array}$

N.B: Mortality rate; control (0/10), sage 50 (0/10), ISO (3/10), ISO+ sage 50 (2/10), ISO+ digoxin $1 \mathrm{mg}(1 / 10)$, ISO+ combined treatment sage oil + digoxin (1/10). Data was expressed as mean $\pm \mathrm{SE}, \mathrm{n}=5, \mathrm{a}, \mathrm{b}, \mathrm{c}$, d or e significantly different from the control, sage oil 50mg, ISO group, ISO+sage oil 50, ISO+Digotoxin $1 \mathrm{mg}$, ISO+ (sage oil 50+Digotoxin 0.5) at $(\mathrm{P}<0.05)$.

Results are shown in Table 1. However, Treatment with sage or digoxin decreased the elevation inCK-MB and cTnI as compared to $\mathrm{CHF}$ group, but didn't normalize it, unlike the combined treatment with (sage 50 and digoxin $0.5)$ as shown in Table 2.

\section{EFFECT OF ISOPRENALINE ON CARDIAC OXIDATIVE} STRESS AND ANTIOXIDANT MARKERS IN RATS

Administration of ISO significantly increased MDA and $\mathrm{NO}$, while decreased the total antioxidant capacity (TAC) as compared to the control group. prophylactic and treatment effects of sage oil on cardiac oxidative stress and antioxidant markers in isoprenaline-induced $\mathrm{CHF}$ in rats are illustrated in Figures 5, 6, respectively.

\section{INFLAMMATORY MARKER}

Administration of ISO significantly increased serum TNFa compared to control group. Prophylactic administration of either sage oil at both tested dosage levels or digoxin significantly decreased this elevation as compared to $\mathrm{CHF}$ group but didn't normalize it (Figure 7a). However, curative administration of either digoxin alone or in combination with sage oil significantly restored as compared to $\mathrm{CHF}$ group (Figure 7b).

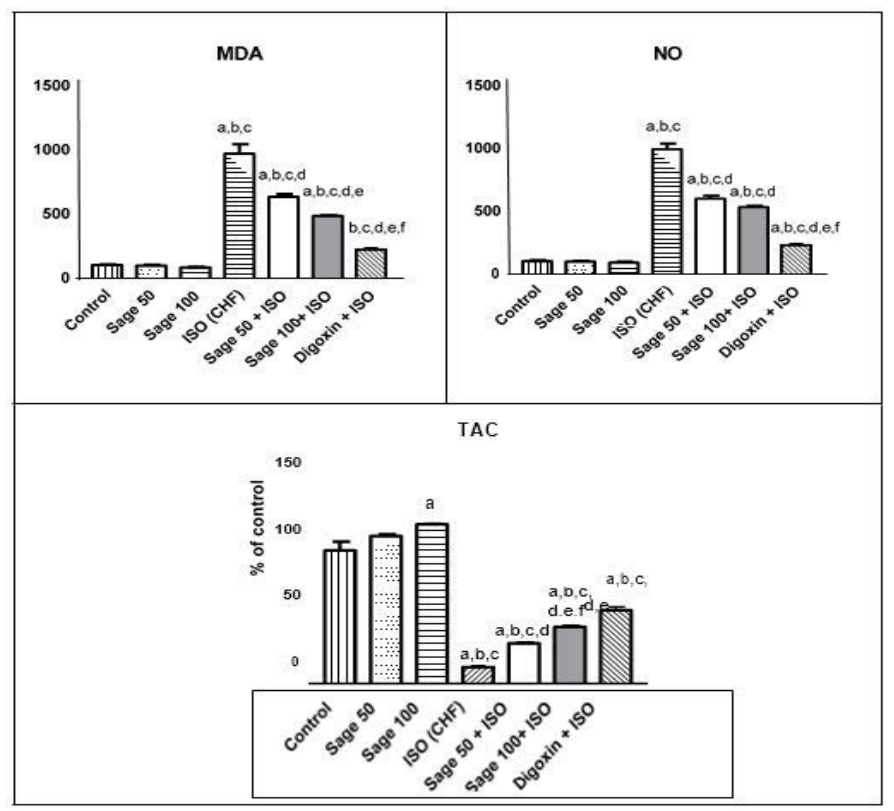

Figure 5: Effect of sage oil on cardiac oxidative stress and antioxidant markers in isoprenaline-induced $\mathrm{CHF}$ in rats (prophylactic). Data was expressed as mean $\pm \mathrm{SE}, \mathrm{n}=5$. a, b, c, d, e or f: Significantly different from the control, sage oil 50mg, sage oil $100 \mathrm{mg}$, ISO (CHF), prophylactic sage oil $50 \mathrm{mg}+$ ISO or prophylactic sage oil $100 \mathrm{mg}+$ ISO respectively at $(\mathrm{P}<0.05)$. 


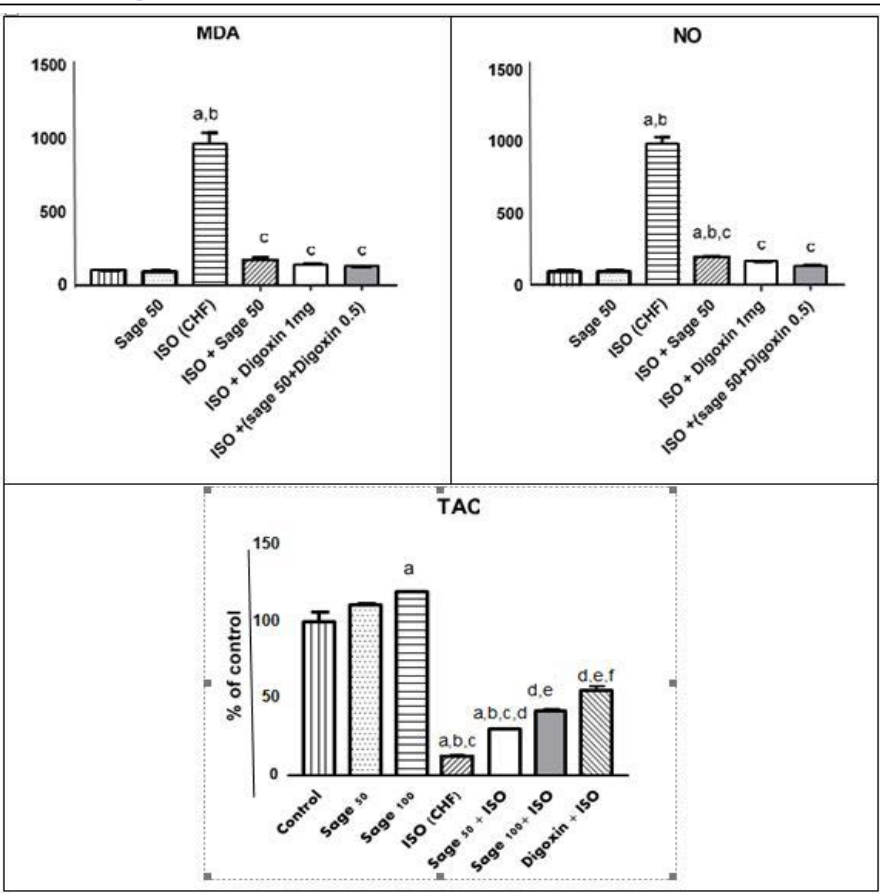

Figure 6: Effect of sage oil on cardiac oxidative stress and antioxidant markers in isoprenaline-induced $\mathrm{CHF}$ in rats (curative). Data was expressed as mean $\pm \mathrm{SE}, \mathrm{n}=5$, a, b, c, d or e significantly different from the control, sage oil $50 \mathrm{mg}$, ISO group, ISO+ sage oil 50, ISO+ Digotoxin $1 \mathrm{mg}$, ISO+ (sage oil 50+Digotoxin 0.5$)$ at $(\mathrm{P}<0.05)$.
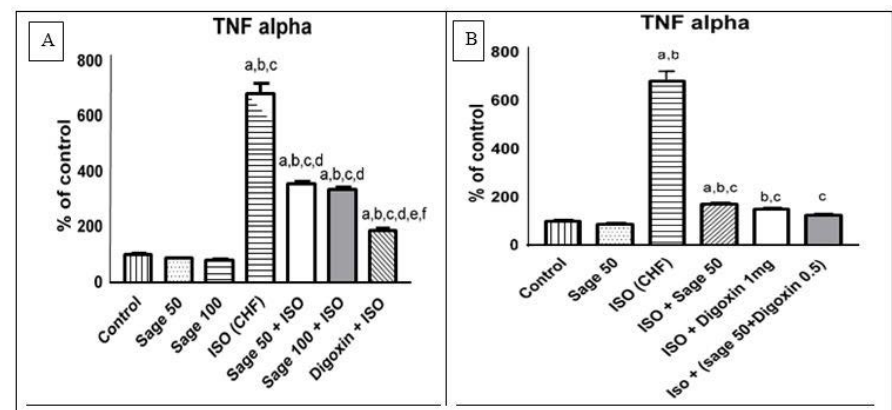

Figure 7: Effect of sage oil on serum inflammatory marker $(\mathrm{TNF}-\alpha)$ level in isoprenaline- induced $\mathrm{CHF}$ in rats. A) prophylactic, B) curative.

Data was expressed as mean $\pm \mathrm{SE}$ of five rats. a, b, c, d, e or f: Significantly different from the control, sage oil $50 \mathrm{mg}$, sage oil $100 \mathrm{mg}$, ISO (CHF), prophylactic sage oil 50mg+ ISO or prophylactic sage oil $100 \mathrm{mg}+$ ISO and ISO+ sage oil 50, ISO+ Digotoxin $1 \mathrm{mg}$, ISO+ (sage oil 50+Digotoxin $0.5)$, respectively at $(\mathrm{P}<0.05)$ using one-way analysis of variance (ANOVA) followed by Tukey's test for multiple comparisons.

\section{Histopathological EXAMINATION}

EFFECT OF H AND E STAIN

Histological examination of heart sections in control negative group (normal non treated) revealed normal histological architecture, where myocardial muscle fibers appeared as branched fibers with central oval nuclei as shown in Figure 8A. Oral administration of sage oil (50 or 100$) \mathrm{mg} / \mathrm{kg} / \mathrm{day}$ alone (group 2,3 ) didn't show any structural changes in the heart tissue as shown in Figure $8 \mathrm{~B}, 8 \mathrm{C}$. In addition to the appearance of inflammatory cell infiltration and dilated blood vessels as illustrated in Figure 8D, E, F. Myocardial sections from groups administered either sage oil as a prophylactic measure still revealed myocardial alterations (myocardial degeneration and dilated blood vessels) as demonstrated in Figure 8G, H, I). Regarding the myocardial sections of the $\mathrm{CHF}$ rats treated with sage oil or digoxin, showed partial improvement as illustrated in Figure 9F, G. While treatment with sage oil 50 and digoxin 0.5 combinations showed almost preserved normal myocardial architecture as shown in Figure $9 \mathrm{H}$.
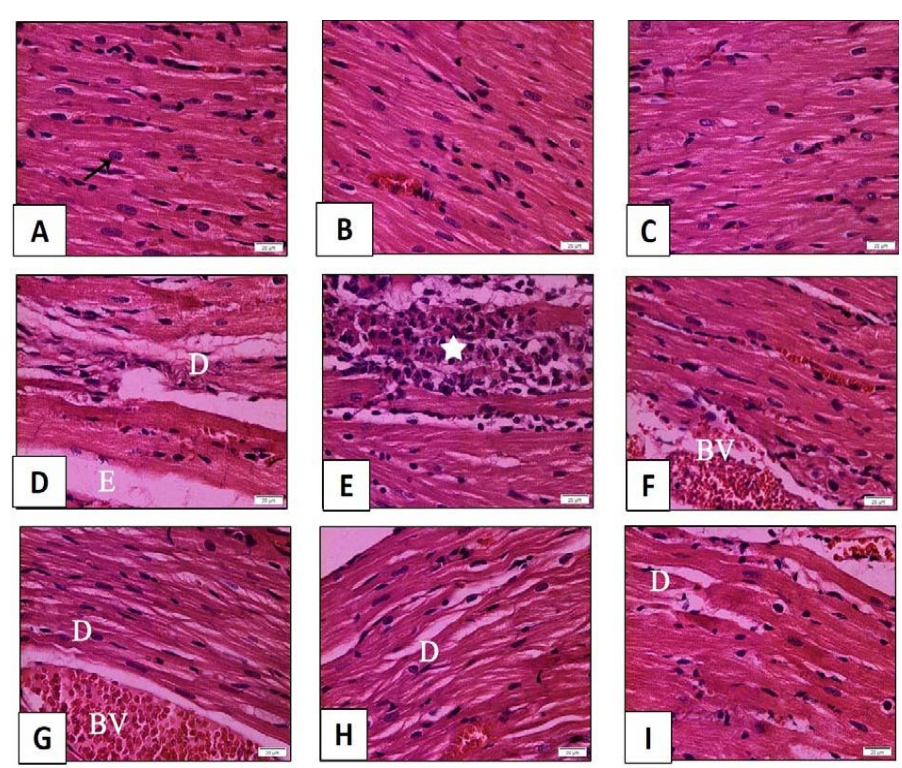

Figure 8: Histopathological examination of transverse sections of HandE stained heart in isoprenaline-induced $\mathrm{CHF}$ in rats $(\mathrm{x} 400)$ (prophylactic).

A: Normal rats showing normal histological architecture. The muscle fibers appear as branched fibers with central oval nuclei (arrow). B and C: Myocardial section of rats received sage oil (50mg and $100 \mathrm{mg} / \mathrm{kg} /$ day/p.o alone) illustrating normal histological structure. D, E, F: Myocardial section of $\mathrm{CHF}$ rats received isoprenaline $(85 \mathrm{mg} / \mathrm{kg} /$ day sc for 2 consecutive days and kept for 2 weeks for induction of heart failure) showing myocardial degeneration and necrosis (D) with interstitial edema (E). Inflammatory cell infiltration (star) and dilated blood vessel (BV) can be seen. G,H,I: Myocardial section of rats received sage oil $(50 \mathrm{mg}, 100 \mathrm{mg} / \mathrm{kg} /$ day $/$ p.o $)$ or digoxin $(1 \mathrm{mg} / \mathrm{kg} /$ day $/$ p.o $) 1$ week before isoprenaline and continued for 2 weeks still revealed myocardial alterations [myocardial degeneration (D) and dilated blood vessels (BV)].

IMMUNOHISTOCHEMICAL STAIN FOR CASPASE 3 (A MARKER OF APOPTOSIS)

Examination of myocardial sections of the control group revealed minimal positive brown cytoplasmic 
immunoreaction in muscle fibers as illustrated in Figure $10 \mathrm{~A}$. As regards sage oil $50 \mathrm{mg}$ or $100 \mathrm{mg}$ groups, the immunoreaction was almost comparable to control as demonstrated in Figure 10B, C. Prophyl active administration of either sage or digoxin demonstrated moderate positive immunoreaction for caspase 3 in myocardial sections as illustrated in Figure 10E, F, G. Treatment with sage oil $50 \mathrm{mg}$ or digoxin $1 \mathrm{mg}$ or their combination showed decreasing in the intensity of immunoreaction as shown in Figure 11D, E, F compared to control positive (isoprenaline) group. The immunohistochemical staining for caspase 3 was morphometrically analyzed for area $\%$ of positive immunoreaction and the results were illustrated in Figure 12.

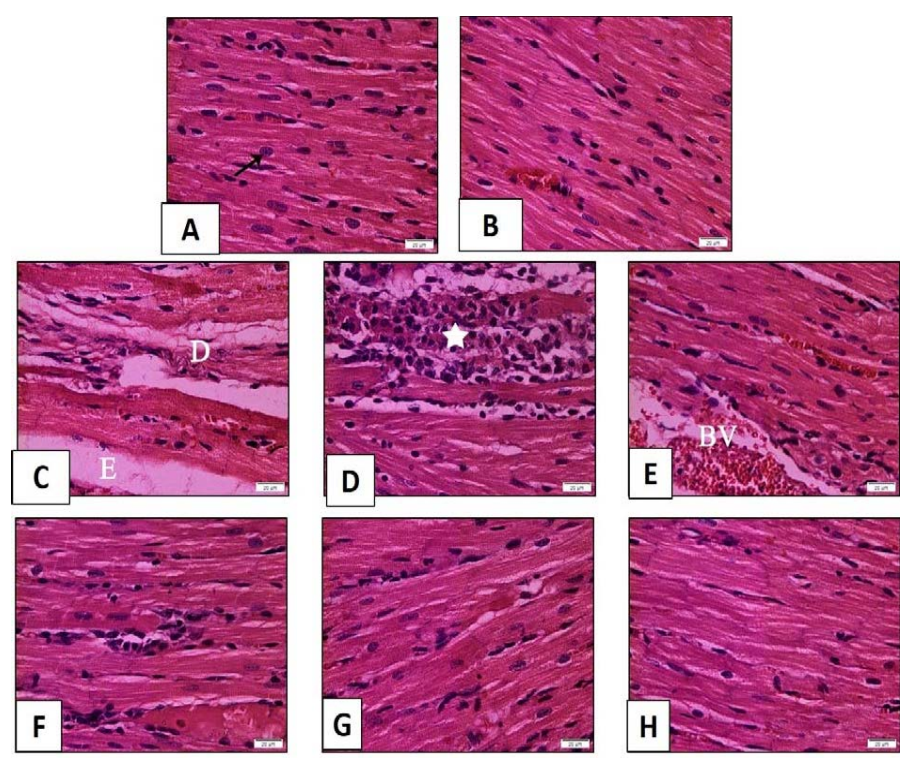

Figure 9: Histopathological examination of transverse sections of $\mathrm{H}$ and $\mathrm{E}$ stained heart in isoprenaline-induced $\mathrm{CHF}$ in rats (x400) (curative).

A: Normal rats showing normal histological architecture. The muscle fibers appear as branched fibers with central oval nuclei (arrow). B: Myocardial section of rats received sage oil $(50 \mathrm{mg} / \mathrm{kg} /$ day $/ \mathrm{p} . o$ alone $)$ illustrating normal histological structure. C, D, E: Myocardial section of $\mathrm{CHF}$ rats received Isoprenaline $(85 \mathrm{mg} / \mathrm{kg} /$ day sc for 2 consecutive days and kept for 2 weeks for induction of heart failure) showing myocardial degeneration and necrosis (D) with interstitial edema (E). Inflammatory cell infiltration (star) and dilated blood vessel (BV) can be seen in F,G: Myocardial section of CHF rats treated with sage oil $(50 \mathrm{mg} / \mathrm{kg} /$ day $/$ p.o $)$ and digoxin $(1 \mathrm{mg} / \mathrm{kg} /$ day $/$ p.o) separately for 2 weeks after induction of heart failure respectively showing partial improvement. $\mathrm{H}$ : Myocardial section of $\mathrm{CHF}$ rats treated with combination of sage oil and digoxin at a dose of (50 and 0.5$) \mathrm{mg} / \mathrm{kg} /$ day $/ \mathrm{p} . \mathrm{o}$ respectively for 2 weeks respectively after induction of heart failure demonstrating almost preserved the normal myocardial architecture.
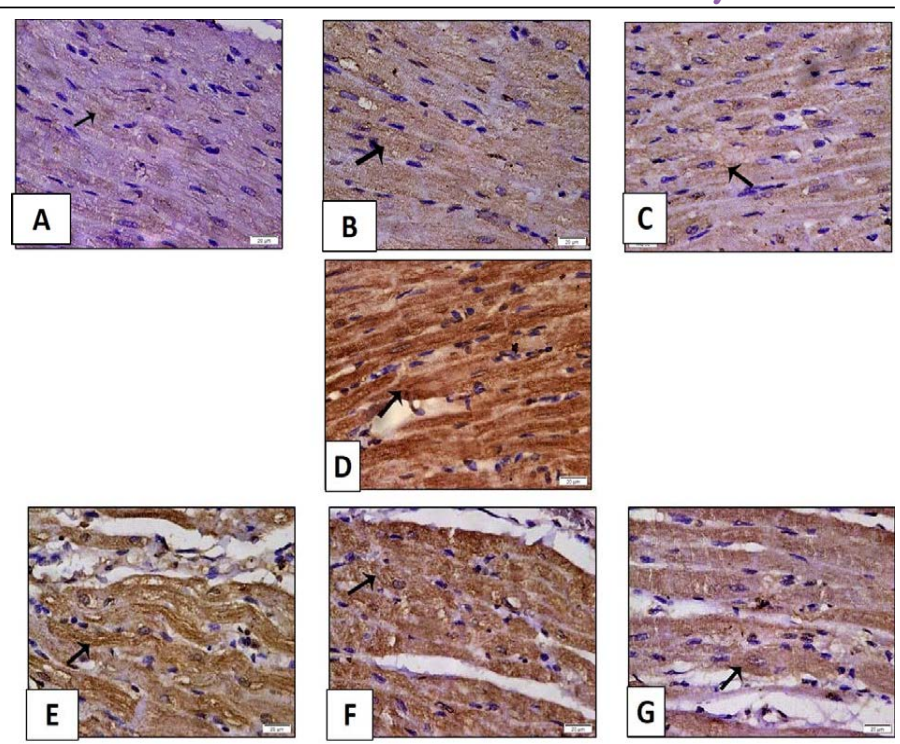

Figure 10: Histopathological examination of transverse sections of caspase 3 immuno- stained heart in isoprenalineinduced $\mathrm{CHF}$ in rats ( $\mathrm{x} 400)$ (prophylactic).

A: Control group illustrating minimal positive brown cytoplasmic immunoreaction in muscle fibers. B, C: Myocardial section of rats received sage oil $(50 \mathrm{mg}$ or $100 \mathrm{mg} / \mathrm{kg} /$ day $/$ p.o alone) showing positive caspase 3 immunoreaction which is almost comparable to control. D: Myocardial section of CHF rats received isoprenaline $(85 \mathrm{mg} / \mathrm{kg} /$ day sc for 2 consecutive days and kept for 2 weeks for induction of heart failure) showing strong extensive positive immunoreaction. E, F, and G: Myocardial section of rats received sage oil $(50 \mathrm{mg}, 100 \mathrm{mg} / \mathrm{kg} /$ day $/$ p.o) or digoxin $(1 \mathrm{mg} / \mathrm{kg} /$ day $/$ p.o $) 1$ week before isoprenaline and continued for 2 weeks respectively illustrating moderate positive cytoplasmic immunoreaction for caspase 3.

\section{MASSON TRICHROME STAIN FOR COLLAGEN FIBERS}

ISO administration demonstrated widespread of collagen fibers compared to control, indicating fibrosis as demonstrated in Figure 13D. Examination of heart sections of sage oil prophylactic groups was shown in Figure 13E, F, G. Sage oil and digoxin treated group partially attenuated myocardial fibrosis as illustrated in Figure 14D and E. Whereas, combination of (sage oil 50 and digoxin 0.5$) \mathrm{mg} / \mathrm{kg} /$ day $/ \mathrm{p}$.o for the same duration greatly alleviated myocardial fibrosis as demonstrated in Figure 14F. The Masson trichrome staining was quantified as area (\%) of the stained sections using the image analysis software, and the results were represented in Figure 15.

Heart failure (HF) is a progressed end stage of various cardiac disorders, and the common final outcome is cardiac overload or myocardial injury leading to insufficiency in supplying blood to meet the metabolic needs of the body (Karagöz et al., 2016). Several studies confirmed the role of inflammation and oxidative stress in progression of HF (Ide et al., 2000). Isoprenaline, b-adrenergic receptor 
agonist, are liable model of cardiac hypertrophy (Parveen et al., 2011). Administration of high concentration of isoproterenol had been reported to induce severe oxidative stress and result in necrotic lesions in the myocardium of rats (Zhou et al., 2008).
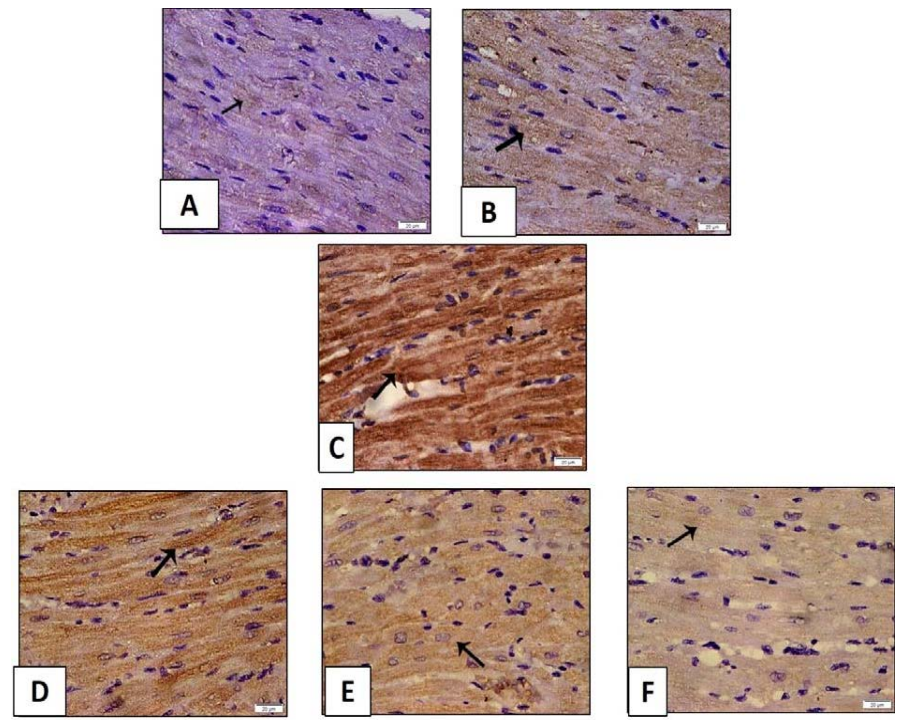

Figure 11: Histopathological examination of transverse sections of caspase 3 immuno- stained heart in isoprenalineinduced $\mathrm{CHF}$ in rats (x400) (curative).

A: Control group illustrating minimal positive cytoplasmic immunoreaction in muscle fibers. B: Myocardial section of rats received (sage oil $50 \mathrm{mg} / \mathrm{kg} /$ day $/$ p.o alone) showing positive caspase 3 immunoreaction which is almost comparable to control. C: Myocardial section of $\mathrm{CHF}$ rats received isoprenaline $(85 \mathrm{mg} / \mathrm{kg} /$ day sc for 2 consecutive days and kept for 2 weeks for induction of heart failure) showing strong extensive positive immunoreaction. D, E: Myocardial section of CHF rats treated with sage oil $(50 \mathrm{mg} /$ $\mathrm{kg} /$ day/p.o) and digoxin ( $1 \mathrm{mg} / \mathrm{kg} /$ day/p.o) separately showing decreased intensity of immunoreaction. F: Myocardial section of $\mathrm{CHF}$ rats treated with combination of sage oil and digoxin at dose of (50 and 0.5$) \mathrm{mg} / \mathrm{kg} /$ day $/$ p.o respectively for 2 weeks after induction of heart failure respectively demonstrating positive immunoreaction that is nearly similar to that of control group.

In the current study, ISO induced heart failure manifested by an increase in the MDA, NO together with decrease in TAC. These results are in agreement with prior investigations which suggested that ISO induced myocardial injury is mainly attributed to the production of free radicals (Ojha et al., 2013; Andalib et al., 2014). Lipid peroxidation is one of the common basic deteriorative reactions following myocardial injury (Panda and Naik, 2008). Moreover, previous investigators provide observations showing that the capacity for nitric oxide synthesis was increased in isoproterenol induced heart failure and was associated with an altered nitric oxiderelated cardiac function, namely regulation of heart rate and a loss of positive inotropic action of nitric oxide in the left ventricular myocytes (Krenek et al., 2009).
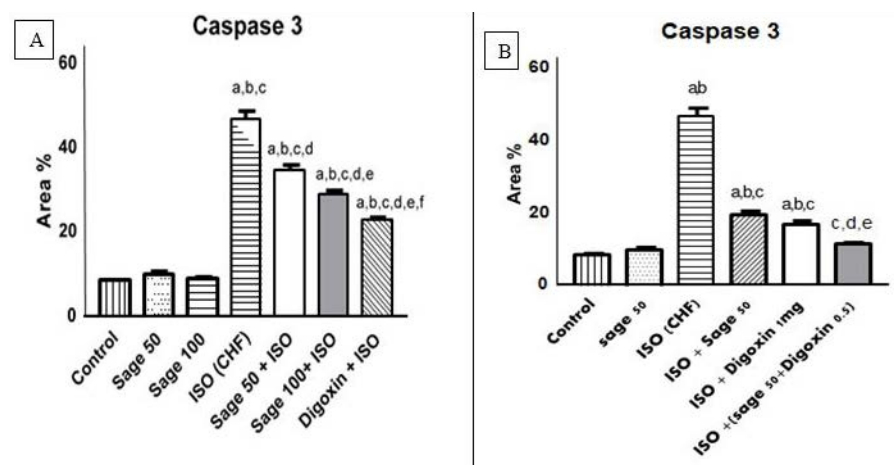

Figure 12: Quantification of the effect of sage oil on cardiac caspase 3 immunoreaction in isoprenaline-induced $\mathrm{CHF}$ in rats; A) prophylactic; B) curative.

Quantification of caspase 3 staining represent the number of stained cells per 10x field was averaged across 10 fields for each rat section. Data was expressed as mean $\pm \mathrm{SE}, \mathrm{n}=$ 5, a, b, c, d, e or f: Significantly different from the control, sage oil $50 \mathrm{mg}$, sage oil $100 \mathrm{mg}$, ISO (CHF), prophylactic sage oil $50 \mathrm{mg}+$ ISO or prophylactic sage oil $100 \mathrm{mg}+$ ISO respectively at $(\mathrm{P}<0.05)$.
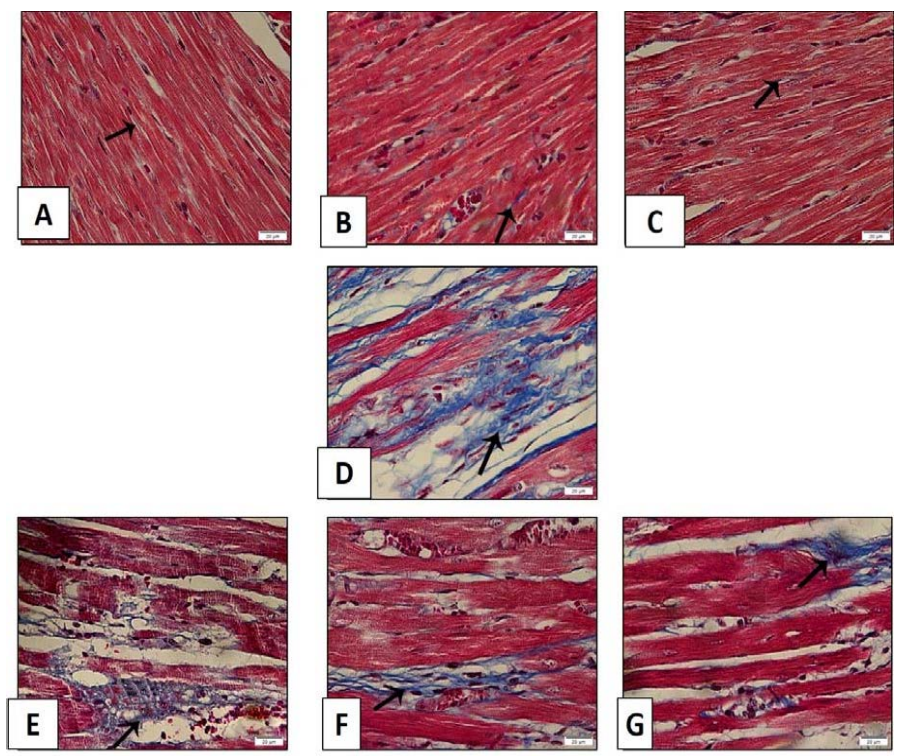

Figure 13: Histopathological examination of transverse sections of Masson trichrome stained heart in isoprenalineinduced CHF in rats ( $\mathrm{x} 400)$ (prophylactic).A: Control group illustrating few collagen fibers in-between the muscle fibers. B,C: Treatment with sage oil (50 or 100) $\mathrm{mg} / \mathrm{kg} /$ day $/ \mathrm{p} . \mathrm{o}$ ) alone showing minimal collagen fibers.D: CHF group received isoprenaline $(85 \mathrm{mg} / \mathrm{kg} /$ day $/ \mathrm{sc}$ for 2 consecutive days and kept for 2 weeks for induction of heart failure demonstrating widespread of collagen fibers.E,F,G: Myocardial sections of rats received sage oil $(50 \mathrm{mg}, 100 \mathrm{mg} / \mathrm{kg} /$ day $/$ p.o) or digoxin $(1 \mathrm{mg} / \mathrm{kg} /$ day $/$ p.o $)$ 1 week before isoprenaline and continued for 2 weeks respectively illustrating moderate amount of collagen fibers. 

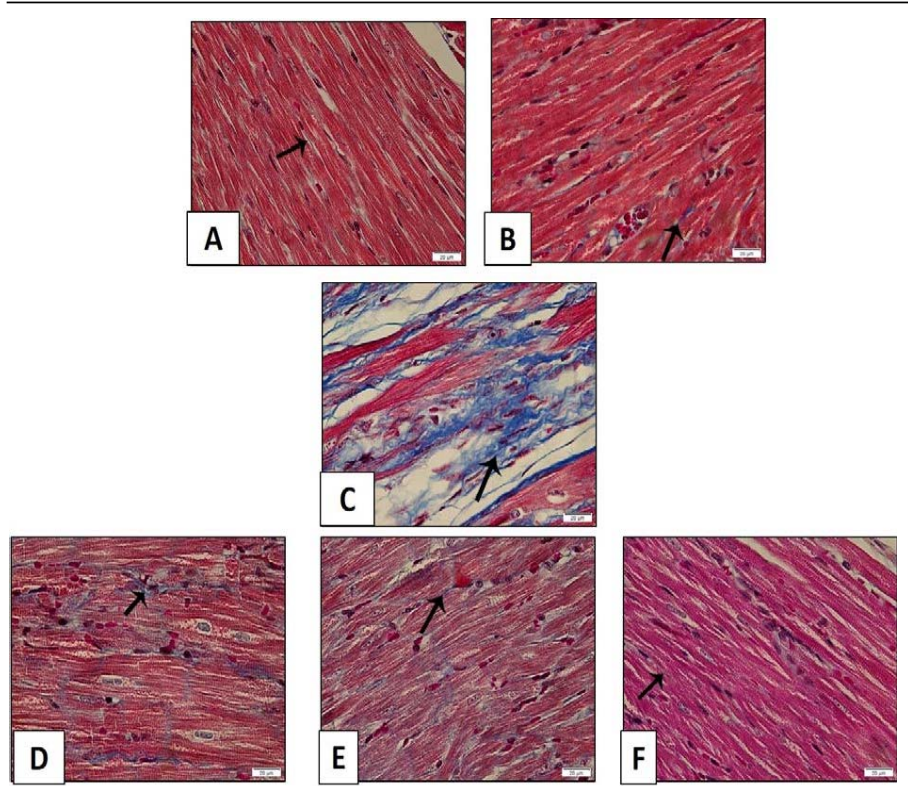

Figure 14: Histopathological examination of transverse sections of Masson trichrome stained heart in isoprenalineinduced $\mathrm{CHF}$ in rats (x400) (curative). A: Control group illustrating few collagen fibers in-between the muscle fibers. B: Treatment with (sage oil $50 \mathrm{mg} / \mathrm{kg} /$ day/p.o) alone showing minimal collagen fibers. C: CHF group received isoprenaline $(85 \mathrm{mg} / \mathrm{kg} / \mathrm{day} / \mathrm{sc}$ for 2 consecutive days and kept for 2 weeks for induction of heart failure demonstrating widespread of collagen fibers. D, E: CHF rats treated with sage oil $(50 \mathrm{mg} / \mathrm{kg} / \mathrm{day} / \mathrm{p} . \mathrm{o})$ and digoxin $(1 \mathrm{mg} / \mathrm{kg} / \mathrm{day} / \mathrm{p} . \mathrm{o})$ for 2 weeks after induction of heart failure to $\mathrm{CHF}$ rats separately showing partially attenuated myocardial fibrosis. F: Myocardial section of $\mathrm{CHF}$ rats treated with combination of sage oil and digoxin at dose of (50 and 0.5$) \mathrm{mg} / \mathrm{kg} /$ day/p.o respectively for 2 weeks after induction of heart failure respectively demonstrating greatly alleviated myocardial fibrosis.

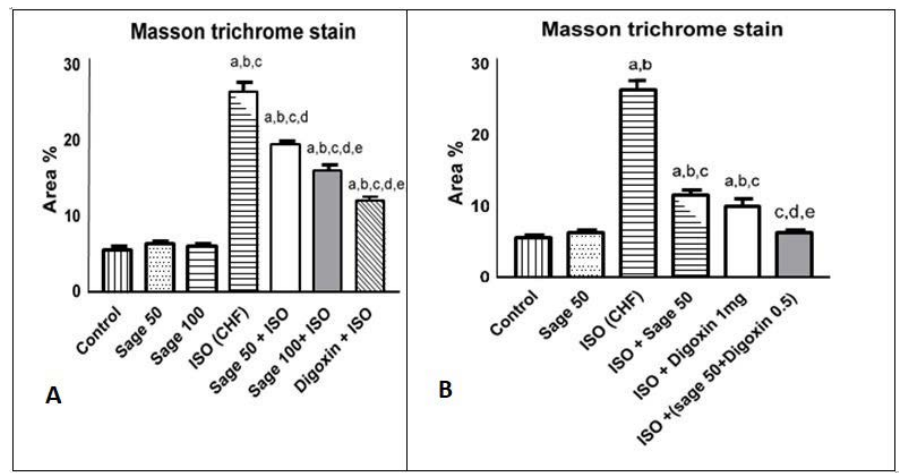

Figure 15: Quantification of the effect of sage oil on cardiac collagen fibers stained with Masson trichrome in isoprenaline-induced $\mathrm{CHF}$ in rats. A) prophylactic B) curative, $10 \mathrm{x}$ fields were averaged across 10 fields for each rat section. Data was expressed as mean $\pm S E, n=5$, $\mathrm{a}, \mathrm{b}, \mathrm{c}, \mathrm{d}$, e or f: Significantly different from the control, sage oil $50 \mathrm{mg}$, sage oil $100 \mathrm{mg}$, ISO (CHF), prophylactic sage oil $50 \mathrm{mg}+$ ISO or prophylactic sage oil $100 \mathrm{mg}+\mathrm{ISO}$ respectively at $(\mathrm{P}<0.05)$.
The non significant change in oxidative, inflammatory, cardiac, apoptotic and fibrotic markers with sage essential oil prophylactic admiration versus control group is along with (Alshubaily and Jambi, 2018). However, sage oil $100 \mathrm{mg}$ treated group showed significant increase in antioxidant marker as compared to control group. This is in accordance with (Alkan et al., 2012) who reported significant increase in antioxidant enzymes in heart tissue upon oral supplementation of rats with sage methanolic extract at $150 \mathrm{mg} / \mathrm{kg}$ for 7 days and in rats liver tissues with $0.052 \mathrm{ml} / \mathrm{kg}$ sage essential oil El-Hosseiny et al. (2016). On the other hand, non significance change in CAT, GSH, and SOD in heart tissue upon administration of sage water extract $1 \mathrm{ml} / \mathrm{kg}$ for 8 weeks also was reported (Alshubaily and Jambi, 2018). Furthermore, sage essential oil enhances the in-vivo antioxidant defense in Co-amoxiclav induced hepatotoxicity in rats (E1-Hosseiny et al., 2016).

However, treatment administration significantly improved the increased level of $\mathrm{NO}$ and decreased level of TAC as compared to ISO group, but it didn't normalize them. These findings are in agreement with the previous studies which showed the ability of Salvia officinalis extracts to ameliorate the impaired CK-MB, MDA, CAT, GSH and SOD in heart and testicular tissues of rats (Ahmed et al., 2017; Alshubaily and Jambi, 2018).

The former activity could be attributed to its constituents as, Rosmarinic acid, the predominant phenolic compound in sage, which is a strong antioxidant (Lima et al., 2005). There was an increasing evidence attributing its antioxidant activity to the presence of two ortho-dihydroxy groups (catechol structure) (Shan et al., 2005; Büyükbalci and Nehir, 2008). Also, the phenolic diterpenes as carnosic acid, carnosol, caffeic acid and luteolin- 7-glucoside that found in sage were contributed to its antioxidant properties (Stephan et al., 2011). Furthermore 1,8-cineole, major monoterpene component of sage essential oil was reported to have anti-inflammatory, antioxidant and antinociceptive activities (E1-Hosseiny et al., 2016; Amensour et al., 2009) reported that antioxidant effect of Salvia officinalis essential oil. is mainly due to their redox properties, which play an important role in adsorbing and neutralizing free radicals, quenching singlet and triplet oxygen, or decomposing peroxides.

In the current work, ISO induced HF was manifested by significant increase of serum CK-MB, troponin I and heart index. This is in accordance with previous studies, which recorded the significant rise in the activity of serum myocardial injury marker enzyme CK-MB, was an indicator of ISO induced necrotic damage of the myocardial membrane (Parveen et al., 2011). Additionally, it was reported that $\mathrm{cTnI}$ is considered the most specific and sensitive indicator of myocardial cell damage, loss of 
functional integrity and/or permeability of cell membrane (Sabeena et al., 2004). Also, studies stated that cTnI is an accurate indicator for the diagnosis of heart failure (Jarolim et al., 2015).

Also, ISO induced heart failure associated with increased TNF- $\alpha$, that could be explained by previous reports of TNF- $\alpha$ as involved marker in cardiac remodeling and the progression of CHF (Mann, 2002). Moreover, it has been shown that TNF- $\alpha$ induces ROS generation in cardiac myocytes and peripheral muscles (Nakamura et al., 1998). In the current study, administration of sage oil at both dosage levels showed significant improvement in all parameters measured as compared to ISO treated group but their effects were significantly less than the reference treatment digoxin. In addition, the $100 \mathrm{mg}$ dose showed significant improvement over the $50 \mathrm{mg}$ in MDA, antioxidant marker, cardiac, apoptotic and fibrotic markers, on the other hand non-significant difference regarding $\mathrm{NO}$ level and TNF- $\alpha$ were recorded between sage oil $50 \mathrm{mg}$ and 100mg. However, both sage oil doses not restore the parameters to normal. These findings are in accordance with previous studies, which showed the ability of Salvia officinalis oil to ameliorate the increased cTnI, CK- MB, NO and MDA and decreased GSH concentration caused by 5 -Fluorouracil induced cardiotoxicity in rats (Safwat and Mohammed, 2015) and also was supported by histopathological examination, which still revealed myocardial degeneration.

The significant effect of digoxin on increasing $\mathrm{R}$ amplitude is might be due to its positive inotropic effect also it decreased heart rate, which could be due to its negative chronotropic effect. However, significant ST height depression was observed upon ISO administration as compared to control is in accordance with (Krenek et al., 2009). Such abnormalities in ISO induced HF rats might occur due to ISO-induced generation of free radicals and therefore, an increase in oxidative stress causing loss of cell membrane function and consequently cardiac conduction disturbances (Lamiaa et al., 2020). Furthermore, an increase in QRS interval was demonstrated in ISO-induced HF rats that might be due to ventricular dysfunction (Mohamed et al., 2015). However, pretreatment with sage oil $100 \mathrm{mg}$ significantly increased $\mathrm{R}$ amplitude which might be attributed to the antioxidant and free radical scavenging effect of sage oil. Additionally, this is in agreement with (Dhyani et al., 2017), who reported decrease in $\mathrm{R}$ amplitude and in contrary ST height elevation which could be attributed to the disturbance in the conduction system of the heart caused by chronic overstimulation of $\beta$ adrenergic receptor. Post treatment with sage oil $50 \mathrm{mg}$ or digoxin $1 \mathrm{mg}$ either separately or concomitantly $(0.5 \mathrm{mg}$ digoxin and $50 \mathrm{mg}$ sage oil) significantly increased $\mathrm{R}$ amplitude. In addition, administration of the combined therapy or digoxin alone significantly reduced heart rate and improved (decreased) ST height depression as compared to CHF which might be attributed to the antioxidant effect of sage oil, positive inotropic effect and negative chronotropic effect of digoxin as mentioned before.

The above-mentioned biochemical alterations were further confirmed by histopathological examination of cardiac tissues, as ISO caused myocardial degeneration and necrosis with interstitial edema. In addition to, the appearance of inflammatory cell infiltration and dilated blood vessels. This was supported by the significant increase in area percent of caspase 3 immunoreaction indicating apoptotic cardiac myocytes. In addition to the presence of myocardial fibrosis that identified by the significant increase in percent of collagen fibers stained with Masson. Similar findings were recorded in previous studies (E1-Demerdash et al., 2005; Huang et al., 2014; Mohamed et al., 2015; Zhou et al., 2017). The previously mentioned findings were explained based on the fact that inflammatory cytokine have been recognized as a major driving force in progression of apoptosis where TNF- $\alpha$ has been previously revealed to induce cardiomyocyte apoptosis via activation of caspase-3 (Haudek et al., 2007). It was also assumed that fibrosis usually proceeds after sustained and unresolved state of inflammation (Feng and Li, 2010). Pathological increase in extracellular collagen deposition leads to interstitial fibrosis, mechanical stiffness and cardiac diastolic dysfunction (Mingliang et al., 2011). Moreover, fibrosis is considered as a barrier between cardiomyocytes leading to impairment of electrical coupling of cardiomyocytes and cardiac systolic dysfunction (Takeda and Manabe, 2011).

Furthermore, the possible effect of Salvia officinalis essential oil on biochemical parameters in our study was enforced by histopathological examination of myocardial sections of this group where partial improvement of myocardial affection, decreased apoptosis and partial attenuation of myocardial fibrosis were noticed. This was proved morphometrically by the significant alleviations of area percent of caspase 3 and Masson as compared to ISO group. Also, a significant difference versus the control was still recorded. While, pretreatment with sage oil at both dosage levels 50 and $100 \mathrm{mg} / \mathrm{kg}$ significantly improve the biochemical alterations which was confirmed by improvement of the cardiac tissue degeneration induced by ISO administration, however some fields still revealed myocardial alterations, moderate apoptosis and moderate fibrosis which were furtherly supported by the significant difference in area $\%$ of caspase 3 and collagen fiber stained with Masson respectively versus control group. These findings are in concomitant with previous study that showed the effect of ethanolic extract of Salvia officinalis on chlorpyrifos or methomyl induced histopathological 
alterations in the heart as it exhibited nearly normal structure (Ahmed et al., 2017).

\section{CONCLUSIONS AND RECOMMENDATIONS}

From the current study, the data suggested an obvious improvement by the usage of sage oil in treatment of $\mathrm{CHF}$ as a curative agent rather than using it as prophylactic measure. In addition, the superiority of the usage of sage oil in combination with digoxin over sage oil alone. The possible mechanisms underlying this cardioprotective effect of sage oil are due to its antioxidant, anti-inflammatory, antiapoptotic and antifibrotic effects. Additional studies are required for further detailed understanding the mechanisms of the use of sage oil as a prophylactic or a curative agent. Further studies are needed aiming to investigate the therapeutic effects of sage oil on $\mathrm{CHF}$.

\section{NOVELTY STATEMENT}

The main objective of this paper is to evaluate the prophylactic and the curative role of sage oil on ISO-induced $\mathrm{CHF}$ in rats.

Even though many researchers studied effects of alcoholic or aqueous crude extract of sage plant and its oil, very few researchers investigated the effect of sage oil and digoxin combination for treatment of CHF. The data suggested an obvious improvement by the usage of sage oil in treatment of $\mathrm{CHF}$ as a curative agent rather than using it as prophylactic measure. In addition, the superiority of the usage of sage oil in combination with digoxin over sage oil alone. The possible mechanisms underlying this cardioprotective effect of sage oil are due to its antioxidant, anti-inflammatory, antiapoptotic and antifibrotic effects. This data are very useful in using of some natural product in treatment of severe and common disease like CHF.

We studied the Salvia officinal is essential oil and its effect on the heart disease in their work. Though there are similar work, but in the present workthe curative and prophylactic role of sage oil on Isoprenaline (ISO) induced CHF were evaluated in rats and compared with the reference digoxin for the first time.

Furthermore, in our study the possible effect of Salvia officinalis essential oil on biochemical parameters was enforced by histopathological examination of myocardial sections.we reportedthe partial improvement of myocardial affection, decreased apoptosis and partial attenuation of myocardial fibrosis. This was proved morphometrically by the significant alleviations of area percent of caspase 3 and Masson as compared to ISOgroup. Also a significant difference versus the control was still recorded.

From the current study we conclude that the administration of sage oil regularly has a clear role in enhancement diseased patient with $\mathrm{CHF}$ more than using it for prophlaxis therapy.

\section{AUTHOR'S CONTRIBUTION}

Radia Ali and Hossney El banna suggested the idea of this manuscript and planned the study. Sara yousry and Shimaa Ramadan performed the experimental part of this work as well as carried out biochemical analysis and liver histology. All Authors shared manuscript writing, drafting and approval of the manuscript.

\section{CONFLICT OF INTEREST}

The authors have declared no conflict of interest.

\section{REFERENCES}

-Ahmed OM,Ashour MB,AbdElMawgoud AA,Ali MA (2017). Assessment of the preventive effects of salvia officinalis and rutagraveolens ethanolic extracts on chlorpyrifos and methomyl-induced testicular and cardiac toxicities in albino rats. Am. J. Med. Med. Sci., 7(7): 287-301.

•Alkan FU, Gürse FE, Ateş A, Özyürek M, Güçlü K, Altun M (2012). Protective effects of Salvia officinalis extract against cyclophosphamide-induced genotoxicity and oxidative stress in rats. Turk. J. Vet. Anim. Sci., 36(6): 646-654.

-Alshubaily FA, Jambi EJ (2018). The possible protective effect of sage (Salvia officinalis L.) water extract against testes and heart tissue damages of hypercholesterolemic rats. Int. J. Pharma. Phytopharmacol. Res., 8(1): 62-68.

- Amensour M, Sendra E, Abrini J, Bouhdid S, Angel Pérez JA, Fernández L (2009). Total phenolic content and antioxidant activity of myrtle (Myrtus communis) extracts. Nat. Prod. Commun., 4(6): 819-824. https://doi. org/10.1177/1934578X0900400616

-Armitage GG, Berry P (1987). Statistical methods in medical research P. Armitage and G. Berry, Blackwell Scientific Publications, Oxford, U.K., 559.

- Andalib S, Shayanfar A, Khorrami A, Maleki-Dijazi N, Garjani A (2014). Atorvastatin reduces the myocardial content of coenzyme Q10 in isoproterenol-induced heart failure in rats. Drug Res., 64(5): 246-250. https://doi. org/10.1055/s-0033-1357178

-Anderson M, Moore D, Larson D (2008). Comparison of isoproterenol and dobutamine in the induction of cardiac hypertrophy and fibrosis. Perfusion, 23(4): 231-235. https:// doi.org/10.1177/0267659108100708

- Bancroft JD, Gamble M (2008). Theory and practice of histological techniques. $6^{\text {th }}$ Edition, Churchill Livingstone, Elsevier, China.

-Bouajaj S, Benyamna A, Bouamama H, Romane A, Falconieri D, Piras A, Marongiu B (2013). Antibacterial, allelopathic and antioxidant activities of essential oil of Salvia officinalis L. growing wild in the Atlas Mountains of Morocco. Nat. Prod. Res., 27(18): 1673-1676. https://doi.org/10.1080/14 
786419.2012.751600

- Büyükbalci A, Nehir S (2008). Determination of in vitro antidiabetic effects, antioxidant activities and phenol contents of some herbal teas. J. Plant Food Hum. Nutr., 63(1): 27-33. https://doi.org/10.1007/s11130-007-0065-5

-Dhyania V, Kumara J, Bhaskarab T (2017). Thermal decomposition kinetics of sorghum straw via thermogravimetric analysis. Bioresour. Technol., 245(1): 1122-1129. https://doi. org/10.1016/j.biortech.2017.08.189

-Drews O, Tsukamoto O, Liem D, Streicher J, Wang Y, Ping $P$ (2010). Differential regulation of proteasome function in isoproterenol-induced cardiac hypertrophy. Circul. Res., 107(9): 1094-1101. https://doi.org/10.1161/ CIRCRESAHA.110.222364

-E1-Banna H, Soliman M, Al-wabel N (2013). Hepatoprotective effects of thymus and salvia essential oils on paracetamolinduced toxicity in rats. J. Physiol. Pharmacol. Adv., 3(2): 4147. https://doi.org/10.5455/jppa.20130228054608

-El-Demerdash E, Awad A, Taha RM, El-Hady AM, SayedAhmed MM (2005). Probucol attenuates oxidative stress and energy decline in isoproterenol-induced heart failure in rat. Pharmacol. Res., 51(4): 311-318. https://doi.org/10.1016/j. phrs.2004.10.002

-El-Hosseiny LS, Alqurashy NN, Sheweita SA (2016). Oxidative stress alleviation by sage essential oil in co-amoxiclav induced hepatotoxicity in rats. Int. J. Biomed. Sci., 12(2): 71-78.

-Ellison GM, Torella D, Karakikes I, Purushothaman S, Curcio A, Gasparri C, Indolfi C, Cable NT, Goldspink DF, Nadal-Ginard B (2007). Acute beta- adrenergic overload produces myocyte damage through calcium leakage from the ryanodine receptor 2 but spares cardiac stem cells. J. Bio. Chem., 282(15): 11397-11409. https://doi.org/10.1074/jbc. M607391200

- Feng W, Li W (2010). The study of ISO induced heart failure rat model. Exp. Mol. Pathol., 88(2): 299-304. https://doi. org/10.1016/j.yexmp.2009.10.011

- Garjani A, Andalib S, Biabani S, Soraya H, Doustar Y, Garjani A, Maleki- Dizaji N (2011). Combined atorvastatin and coenzyme Q10 improve the left ventricular function in isoproterenol-induced heart failure in rat. Eur. J. Pharmacol., 666(1-3): 135-141. https://doi.org/10.1016/j. ejphar.2011.04.061

- Gerhardt W, Waldenstrom J (1979). Creatine kinase B-Subunit activity in serum after immunoinhibition of M-Subunit activity. Clin. Chem., 25(7): 1274-1280. https://doi. org/10.1093/clinchem/25.7.1274

- Grimm D, Elsner D, Schunkert H, Pfeffer M, Griese D, Bruckschlegel G, Muders F, Riegger GA, Kromer EP (1998). Development of heart failure following isoproterenol administration in the rat: Role of the renin- angiotensin system. Cardiovascu. Res., 37(1): 91-100. https://doi. org/10.1016/S0008-6363(97)00212-5

- Hajrasouliha AR, Tavakoli S, Jabehdar-Maralani P, Shafaroodi H, Borhani AA, Houshmand G, Sadeghipour H, Dehghani M, Dehpour AR (2004). Resistance of cholestatic rats against epinephrine-induced arrhythmia: the role of nitric oxide and endogenous opioids. Eur. J. Pharmacol., 499(3): 307-313. https://doi.org/10.1016/j.ejphar.2004.07.099

- Hamidpour M, Hamidpour R, Hamid pour S, Shahlari M (2014). Chemistry, pharmacology and medicinal property of sage (Salvia) to prevent and cure illnesses such as obesity, diabetes, depression, dementia, lupus, autism, heart disease and cancer. J. Trad. Complemen. Med., 4(2): 82-88. https:// doi.org/10.4103/2225-4110.130373

- Haudek SB, Taffet GE, Schneider MD, Mann DL (2007).TNF provokes cardiomyocyte apoptosis and cardiac remodeling through activation of multiple cell death pathways. J. Clin. Invest., 117(9): 2692-2701. https://doi.org/10.1172/ JCI29134

-Huang D, Ke J, Zhao A, Yang Z, Liang D, Pan J, Liu M (2014). Chen J. establishment and evaluation of isoproterenol induced chronic heart failure and cardiac remodeling model in rats: An experimental study. Int. J. Cardiovascu. Cerebrovascu. D., 2(5): 45-50. https://doi.org/10.2174/221 1334707999140331121333

- Hussain A, Anwar F, Iqbal T, Bhatti I (2011). Antioxidant attributes of four Lamiaceae essential oils. Pak. J. Bot., 43(2): 1315-1321.

-Ide T, Tsutsui H, Kinugawa S, Suematsu N, Hayashidani S, Ichikawa K, Utsumi H, Machida Y, Egashira K, Takeshita A (2000). Direct evidence for increased hydroxyl radicals originated from superoxide in the failing myocardium. Circul. Res., 86(2): 152-157. https://doi.org/10.1161/01. RES.86.2.152

- Jarolim P, Patel PP, Conrad MJ, Chang L, Melenovsky V, Wilson DH (2015). Fully automated ultrasensitive digital immunoassay for cardiac troponin i based on single molecule array technology. Clin. Chem., 61(10): 1283-1291. https:// doi.org/10.1373/clinchem.2015.242081

-Jensen RA, Acton EM, Peters JH (1984). Doxorubicin cardiotoxicity in the rat: comparison of electrocardiogram, transmembrane potential, and structural effects. J. Cardiovascu. Pharmacol., 6(1): 186-200. https://doi. org/10.1097/00005344-198401000-00028

- Karagöz A, Kesici S, Vural A, Usta M, Tezcan B, Semerci T, Teker E (2016). Cardioprotective effects of Viscum album L. ssp. Album (Loranthaceae) on isoproterenol-induced heart failure via regulation of the nitric oxide pathway in rats. Anatolian J. Cardiol., 16(12): 923-930. https://doi. org/10.14744/AnatolJCardiol.2016.6780

- Kiernan J (2001). Histological and histochemical methods: Theory and practice. 3rd ed, London, New York andNew Delhi: Arnold publisher; pp. 111-162.

- Koracivic D, Koracevic G. Djordjevic V, Andrejevic S, Cosic V (2001). Methods for the measurement of antioxidant activity in human fluids. J. Clin. Pathol., 54(5): 356-361. https://doi. org/10.1136/jcp.54.5.356

- Krenek P, Kmecova J, Kucerova D, Bajuszova Z, Musil P, Gazova P, Ochodnicky P, Klimas J, Kyselovic J (2009). Isoproterenol-induced heart failure in the rat is associated with nitric oxide-dependent functional alterations of cardiac function. European J. Heart Fail., 11(2): 140-146. https:// doi.org/10.1093/eurjhf/hfn026

- Lamiaa AA, Omnia FH, Omneya G, Dina FM, Aiman E (2020). NADPH oxidase inhibitor, in isoproterenol-induced myocardial infarction in rats, PLoS One, 15(5). https://doi. org/10.1371/journal.pone.0232413

- Lima CF, Andrade PB, Seabra RM, Fernandes- Ferreira M, Wilson CP (2005). The drinking of a Salvia officinalis infusion improves liver antioxidant status in mice and rats. J. Ethnopharmacol., 97(2): 383-389. https://doi. org/10.1016/j.jep.2004.11.029

- Mann DL (2002). Tumor necrosis factor-induced signal transduction and left ventricular remodeling. J. Cardiac Fail., 8(6): 379-386. https://doi.org/10.1054/jcaf.2002.129253

- Markham R, Young L, Fraser IS (1995). An amplified ELISA 
for human tumor necrosis factor alpha. Eur. Cyt. Network, 6(1): 49-54.

- McMurray JJV, Adamopoulos S, Anker SD, Auricchio A, Bohm M, Dickstein K, Falk V, Lip G Y H, Maggioni A P, Parkhomenko A, Pieske B M, Popescu B A, Rønnevik P K, Rutten F H, Schwitter J Seferovic P, Stepinska J, Trindade P T, Voors A A, Zannad F, Zeiher A(2012). ESC committee for practice guidelines. ESC guidelines for the diagnosis and treatment of acute and chronic heart failure 2012: The task force for the diagnosis and treatment of acute and chronic heart failure 2012 of the European Society of Cardiology. Developed in collaboration with the Heart Failure Association (HFA) of the ESC. Eur. J. Heart Fail., 14(8): 803-869.

-Mingliang R, Bo Z, Zhengguo W (2011). Stem cells for cardiac repair: Status, mechanisms, and new strategies. Stem Cells Int., 310928: 1-8. https://doi.org/10.4061/2011/310928

-Mohamed SS, Ahmed LA, Attia WA, Khattab MM (2015). Nicorandil enhances the efficacy of mesenchymal stem cell therapy in isoproterenol-induced heart failure in rats. Biochem. Pharmacol., 98(3): 403-411. https://doi. org/10.1016/j.bcp.2015.10.004

• Nakamura K, Fushimi K, Kouchi H, Mihara K, Miyazaki M, Ohe T, Namba M (1998). Inhibitory effects of antioxidants on neonatal rat cardiac myocyte hypertrophy induced by tumor necrosis factor-alpha and angiotensin II. Circulation, 98(8): 794-799. https://doi.org/10.1161/01.CIR.98.8.794

- Ohkawa H, Ohishi N, Yagi K (1979). Assay for lipid peroxides in animal tissues by thiobarbituric acid reaction. Anal. Biochem., 95(2): 351-358. https://doi.org/10.1016/00032697(79)90738-3

- Ojha S, Golechha M, Kumari S, Bhatia J, Arya DS (2013). Glycyrrhizaglabra protects from myocardial ischemia reperfusion injury by improving hemodynamic, biochemical, histopathological and ventricular function. Experiment. Toxicol.Pathol.,65(1-2):219-227.https://doi.org/10.1016/j. etp.2011.08.011

- Panda VS, Naik SR (2008). Cardioprotective activity of Ginkgo biloba Phytosomes in isoproterenol-induced myocardial necrosis in rats: a biochemical and histoarchitectural evaluation. Exp. Toxicol. Pathol., 60(4-5): 397-404. https:// doi.org/10.1016/j.etp.2008.03.010

- Parveen A, Babbar R, Agarwal S, Kotwani A, Fahim M (2011). Mechanistic clues in the cardioprotective effect of terminalia arjuna bark extract in isoproterenol-induced chronic heart failure in rats. Cardiovasc. Toxicol., 11(1): 48-57. https:// doi.org/10.1007/s12012-010-9099-2

- Patel V, Upaganlawar A, Zalawadia R, Balaraman R (2010). Cardioprotective effect of melatonin against isoproterenol induced myocardial infarction in rats: A biochemical, electrocardiographic and histoarchitectural evaluation. Eur. J. Pharmacol., 644(1-3): 160-168. https://doi.org/10.1016/j. ejphar.2010.06.065

- Rami K, Li Z (2011). Antimicrobial activity of essential oil of
Salvia officinalis L. collected in Syria. Afr. J. Biotechnol., 10(42): 8397-8402. https://doi.org/10.5897/AJB10.2615

-Remião F, Carmo H, Carvalho F, Bastos ML (2001). Copper enhances isoproterenol toxicity in isolated rat cardiomyocytes: effects on oxidative stress. Cardiovascu. Toxicol., 1(3): 195204. https://doi.org/10.1385/CT:1:3:195

- Sabeena FK, Anandan R, Kumar SH, Shiny KS, Sankar TV, Thankappan TK (2004). Effect of squalene on tissue defense system in isoproterenol-induced myocardial infarction in rats. Pharmacol. Res., 50(3): 231-236. https://doi. org/10.1016/j.phrs.2004.03.004

-Stephan GW, Laura NT, Benno F, Zimmermann, Wolf S, Dirk WL (2011). Antioxidant capacity and polyphenolic composition as quality indicators for aqueous infusions of Salvia officinalis L. (sage tea). J. Pharmacol., 33(2): 342-349. https://doi.org/10.3389/fphar.2011.00079

- Safwat GM, Mohammed ET (2015). Salvia officinalis oil improves the atherogenic index and cardiotoxicity in albino rats treated with 5- fluorouracil. Int. J. Pharma. Biol. Sci., 6(2): 59-66.

-Shan B, Cai YZ, Sun M, Corke H (2005). Antioxidant capacity of 26 spice extracts and characterization of their phenolic constituents. J. Agric. Food Chem., 5;53(20): 7749-7759. https://doi.org/10.1021/jf051513y

- Suvarna SK, Layton C, Bancroft JD (2012). Connective and mesenchymal tissue with their stains. In: Bancroft's Theory and practice of histological techniques, $7^{\text {th }}$ ed., Elsevier Health Sciences, Churchill Livingstone, pp. 187-214. https://doi.org/10.1016/B978-0-7020-4226-3.00011-1

- Stuehr DJ, Marletta MA (1985). Mammalian nitrate biosynthesis: Mouse macrophages produce nitrite and nitrate in response to Escherichia coli lipopolysaccharide. Proc. Natl. Acad. Sci. U.S.A., 82(22): 7738-7742. https:// doi.org/10.1073/pnas.82.22.7738

- Takeda N, Manabe I (2011). Cellular interplay between cardiomyocytes and nonmyocytes in cardiac remodeling. Int. J. Inflamm., 535241: 1-13. https://doi. org/10.4061/2011/535241

-Wang Y, Ma Q, Zhang S, Liu H, Zhao B, Du B, Wang W, Lin P, Zhang Z, Zhong Y, Kong D (2020). Digoxin enhances the anticancer effect on non-small cell lung cancer while reducing the cardiotoxicity of adriamycin. Pharmacology, 28(2): 1-9. https://doi.org/10.3389/fphar.2020.00186

-Zhou R, Xu Q, Zheng P, Yan L, Zheng J, Dai G (2008). Cardioprotective effect of fluvastatin on Isoproterenolinduced myocardial infarction in rat. Eur. J. Pharmacol., 586(1-3): 244-250. https://doi.org/10.1016/j. ejphar.2008.02.057

-Zhou R, Ma P, Xiong A, Xu Y, Wang Y, Xu Q (2017). Protective effects of low-dose rosuvastatin on isoproterenol-induced chronic heart failure in rats by regulation of DDAHADMA- NO Pathway. J. cardiovascu. Ther., 35(2). https:// doi.org/10.1111/1755-5922.12241 